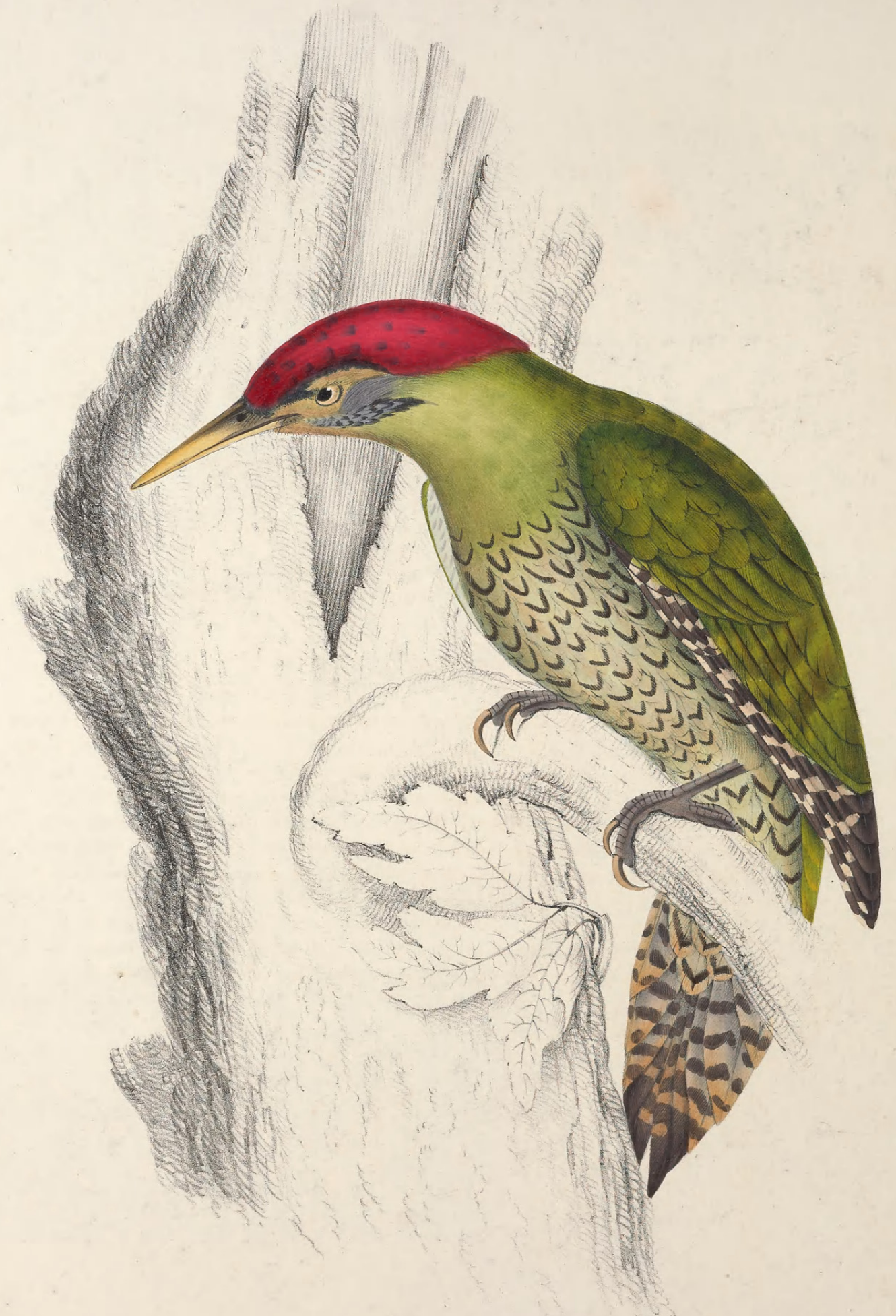

PICLS SQUA MI TUS 


\section{'TAB. XLVIII.}

\section{PICUS SQUAMATUS.}

Pic. supra viridis, uropygio sublutescenti; gulâ juguloque viridi-canis; capite coccineo ; strigâ superoculari, alterâ suboculari, abdomineque viridi-albis, hoc atro squamato; strigâ superciliari alterâque utrinque mentali atris; remigibus rectricibusque fusco-atris, illis externè, his utrinque albo maculatis.

Longitudo corporis, $12 \frac{3}{4}$ unc. ; rostri, 2 ; tarsi, $1 \frac{1}{2} ;$ caude, 5 .

THE present species, while it is closely allied in form to the last-figured bird, and most strictly connected with the natural division alluded to in the preceding description, offers some essential marks of distinction in the plumage ; one of the most conspicuous of which is the different characters of the feathers on the breast, which are marked by beautiful and regular scales, while in the Picus occipitalis an uniform and totally different colouring prevails on the same parts. To this character the bird owes its specific name. Its locality is believed, like that of Picus occipitalis, to be confined solely to the higher parts of the mountains.

The top of the head, and occiput are scarlet; above and below the eye passes a yellowish white streak; a black line extends also from the base of the lower mandible along the sides of the neck; the upper surface is of a bright green colour; the quill-feathers and tail dull olive black barred with white; the throat and breast are greyish green; the abdomen and under surface of a still lighter tint elegantly marked with black scales, closely and regularly disposed; the bill is yellowish white, becoming horn-brown at the base; the tarsi are brown.

The figure is of the natural size. 


\section{$2 \mathrm{BHL}$ Biodiversity Heritage Library}

Gould, John. 1831. "Picus squamatus [Tab. XLVIII]." A century of birds from the Himalaya Mountains -. https://doi.org/10.5962/p.323594.

View This Item Online: https://www.biodiversitylibrary.org/item/132967

DOI: https://doi.org/10.5962/p.323594

Permalink: https://www.biodiversitylibrary.org/partpdf/323594

\section{Holding Institution}

Smithsonian Libraries

\section{Sponsored by}

Biodiversity Heritage Library

\section{Copyright \& Reuse}

Copyright Status: Public domain. The BHL considers that this work is no longer under copyright protection.

This document was created from content at the Biodiversity Heritage Library, the world's largest open access digital library for biodiversity literature and archives. Visit BHL at https://www.biodiversitylibrary.org. 